\title{
A epístola como exemplo de texto escrito
}

\author{
MARCOS MARTINHO DOS SANTOS \\ Faculdade de Filosofia, Letras e Ciências Humanas \\ Universidade de São Paulo
}

\begin{abstract}
RESUMO: Valendo-me das Epístolas de Horácio e do confronto destas com a Poética e a Retórica de Aristóteles, primeiro investigo a hypókrisis da epístola, de modo a qualificar esta como essencialmente graphiké e, dai, destinada, não a ouvinte ou espectador, mas a leitor. Depois deduzo dessa qualidade, que respeita à elocução, a matéria mais conveniente à epístola, que respeita à invenção, de modo a entender tal conveniência como prépon da epístola; por exemplo, nas Epístolas de Horácio, o elogio do campo e repúdio da cidade seriam, nesse sentido, não um gosto particular do Autor, mas uma matéria que, de modo geral, se harmoniza com elocução que, justamente, se dirige ao leitor, isto é, ao âmbito privado [= campo], e repudia o ouvinte e espectador, isto é, o âmbito público [= cidade].
\end{abstract}

PALAVRAS-CHAVE: epistolografia; Horácio; poética; retórica; Aristóteles; hypókrisis; escrita e oralidade; prépon.

\section{A léxis graphiké da epístola e a matéria do elogio ao campo e repúdio da cidade}

Na Epístola 1 do Livro 2, Horácio aponta a Augusto as várias causas que o afastam, em geral, da prática da poesia, seja da poesia dramática (v. 177-213), seja da lírica (v. 21444), seja da épica (v. 245-50). Já do que o afasta da primeira, em particular, alega o desvirtuamento do gosto do público, seja da plebécula seja do cavaleiro (v. 186-7), pois que todos se comprazem mais em admirar os adereços que enfeitam o palco que em ouvir o texto que lhes narra o ator (v. 182-207). Assim se queixa Horácio:

Saepe etiam audacem fugat hoc terretque poetam, quod numero plures, virtute et honore minores, indocti stolidique et depugnare parati, si discordet eques, media inter carmina poscunt aut ursum aut pugiles: his nam plebecula gaudet. verum equitis quoque iam migravit ab aure voluptas omnis ad incertos oculos et gaudia vana.

[. . . .] si foret in terris, rideret Democritus, [...]

[. . . $]$ 
spectaret populum ludis attentius ipsis, ut sibi praebentem nimio spectacula plura: scriptores autem narrare putaret asello fabellam surdo [...]

[. . . .]

Garganum mugire putes nemus aut mare Tuscum; tanto cum strepitu ludi spectantur et artes divitiaeque peregrinae, quibus oblitus actor cum stetit in scaena, concurrit dextera laevae. "dixit adhuc aliquid?" "nil sane." "quid placet ergo?" “lana Tarentino violas imitata veneno" (Hor. Ep. II 1,182-207)

Amiúde ainda isto afasta e aterra o poeta audacioso: que os amplos em número, diminutos em virtude e honra, indoutos e estultos e prontos a lutar se discorda o cavaleiro, pedem, em meio aos poemas, ora o urso ora os pugilistas, pois nisso se regozija a plebécula. Na verdade, também do cavaleiro o prazer migrou todo do ouvido para os incertos olhos e gozos vãos.

[. . . .]

Se estivesse na terra, riria Demócrito, [...]

[. . . .]

admiraria o público mais atentamente que aos mesmos jogos, como a apresentar-lhe espetáculos bem mais numerosos;

já os escritores pensaria que narram a fábula

a um asno surdo. [...]

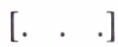

Pensarias que muge o bosque do Gargano ou o mar da Toscana, tal o estrépito com que se admiram os jogos e artes, bem como as riquezas estrangeiras, pelas quais o ator é esquecido quando, ao parar em cena, a destra encontra a esquerda.

"Ele disse algo ainda?" "Nada, não." "Que aplaudem, então?"

"A lã imitando o violeta com o pigmento de Tarento."

Ainda em particular, Horácio distingue entre o público do poeta lírico e o do trágico: o daquele atentaria, ao menos, no que o poeta lhe narra, já que, não deparando com qualquer cenário, que admire como espectador, tem apenas o texto, que aprecie como leitor:

\section{[...] Qui se lectori credere malunt quam spectatoris fastidia ferre superbi (id. ib. II 1,214-5) \\ [...] Que preferem fiar-se do leitor a suportar a soberba de um espectador enfastiado.}

Nesse sentido, enfim, o público da lírica e, daí, a mesma poesia lírica seriam superiores ao público da tragédia e a toda a poesia trágica. 
Ora, a crítica de Horácio parece ser, antes de tudo, um lugar-comum das artes poéticas e retóricas gregas e latinas, a julgar, por exemplo, pelos argumentos de Aristóteles para a superioridade da epopéia sobre a tragédia. Segundo o Filósofo, a alegada superioridade deve-se a que o público da epopéia, de um lado, dispensa, o da tragédia, de outro, reclama aparato visual, seja o cenário do palco seja a mímica do ator; esta, aliás, Aristóteles designa ora por kínesis, ou movimento, com que alude à expressão corporal do ator, ora por skhémata, ou feições, com que alude à expressão facial:

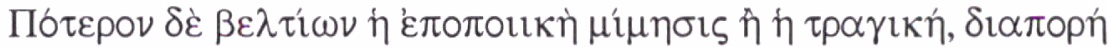

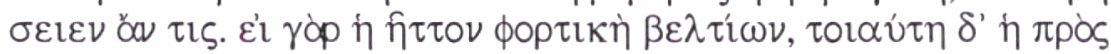

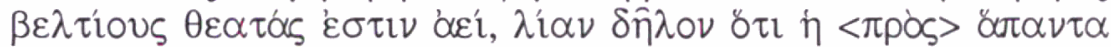

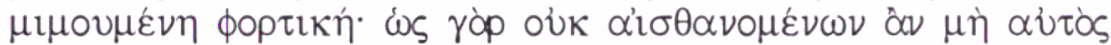

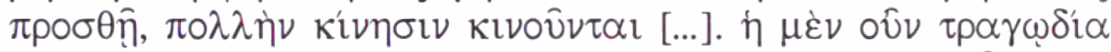

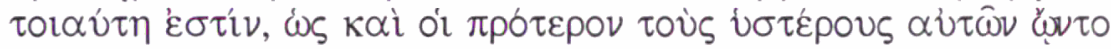
í

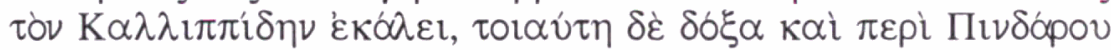

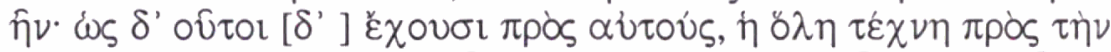

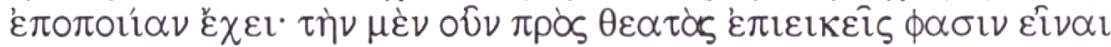

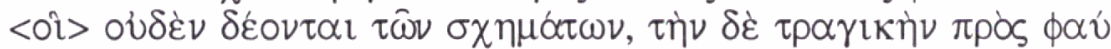

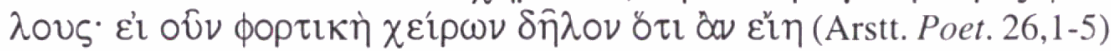

Ora, poder-se-ia discutir se é preferível a imitação [mímesis] épica ou a trágica. Pois se a menos grosseira é preferível, e tal é sempre a voltada para espectadores preferíveis, [está] bem claro que a que tudo imita é grosseira. Pois, por não serem apreciados se [o espectador] mesmo não se impõe, [os atores] movimentam-se com amplo movimento [pollèn kínesin kinoûntai] [...]. Ora, a tragédia, pois, é tal como também os atores de antes criam os pósteros, pois assim Minisco chamava Calípides, que balançava demais, de macaco, e tal era a opinião também acerca de Píndaro. Ora, assim como estes estão para aqueles, toda a técnica [dramática] está para a epopéia. Dizem, pois, que esta, de um lado, é para espectadores superiores, que não necessitam das feições [skhemáton], a [técnica] trágica, de outro, para parvos. Se, pois, é grosseira, claro que é inferior.

Ora, tal argumento concorda, antes de tudo, com aquele outro, essencial para a qualificação aristotélica da poesia, pelo qual se distinguem mímesis visual e mímesis sonora:

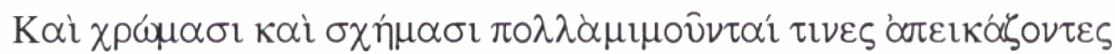

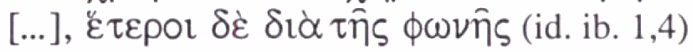

Uns, tanto por cores como por feições [skhémasi], imitam [mimoûntai] muitas coisas ao fazer a imagem [destas] [...], outros, porém, por meio da voz [phonês].

Como se vê desse passo, com que se abre a Poética, os skhémata tanto se equiparam à mímesis visual como, por isso mesmo, se distinguem da mímesis sonora. Ora, a tragédia seria, então, uma espécie poética que acoplaria os skhémata, elemento visual, à phoné, elemento sonoro. Daí, então, o público daquela, por algum desvirtuamento do 
gosto, teria sido levado a preferir a phoné, a parte essencial do gênero poético, em favor dos skhémata, a parte acidental da espécie trágica. Enfim, assim como Aristóteles prefere a epopéia, assim Horácio prefere a lírica à tragédia; assim como aquele, assim este critica a tragédia.

Ora, as críticas do Filósofo e do Epistológrafo atentam, antes de tudo, para o elemento visual que se acopla ao sonoro e, daí, acaba mesmo por sobrepor-se a este; demais, tal elemento designa-se, na linguagem de Aristóteles, por kínesis e skhémata. Ora, tais são os termos técnicos que, nas artes retóricas e poéticas gregas e latinas, se empregam para designar uma parte do estudo da oratória e poesia, a saber, a hypókrisis, em grego, ou actio, em latim, isto é, a recitação ou ação. Demais, tal parte considera a kínesis ou motus, isto é, os movimentos corporais que acompanham a enunciação de um texto, e os skhémata ou facies, isto é, as expressões faciais. Por isso, na verdade, Aristóteles, tão logo expõe sua crítica à tragédia, diz que se trata de uma acusação, não a tudo que pertence à poética, mas só ao que pertence à hypókrisis:

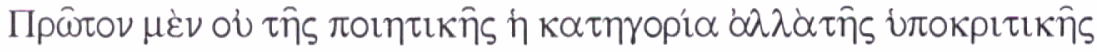
(id. ib. 26,6)

Primeiro, pois, a acusação é [acusação] não da poética, mas da récita [hypokritikês].

Mas, então, a tragédia seria, das espécies poéticas, apenas aquela que, pelo uso do cenário do palco e dos gestos e feições do ator, mais facilmente abre caminho ao relevo da hypókrisis (id. ib. 19,7). Logo, também as outras espécies poderiam incorrer em tal excesso, ainda que menos facilmente. Por isso, na verdade, Aristóteles, tão logo critica a hypókrisis da tragédia, absolve, em particular, a tragédia que não faça preponderar a hypókrisis, e condena, em geral, qualquer espécie poética que ponha em relevo a hypókrisis.

Assim, por um lado, também a tragédia pode atingir seu fím próprio à maneira da epopéia, isto é, sem recorrer à kínesis:

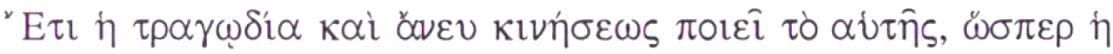

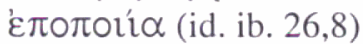

Demais, também sem movimento [kinéseos] a tragédia perfaz o que é dela, como a epopéia,

contanto que, dada a tragédia, o efeito desta no público resulte antes do encadeamento mesmo dos atos (id. ib. 14,1: ex autês tês systáseos tôn pragmáton), que se narra aos ouvidos do público, que do espetáculo (id. ib. 14,1: ek tês ópseos), que se apresenta aos olhos; ou ainda, contanto que a tragédia se dirija ao público antes como a ouvinte (id. ib. 14,2: tòn akoúonta) que como a espectador (id. ib. 14,2: áneu toû horân):

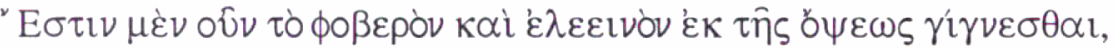

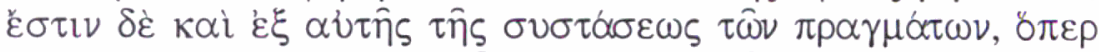

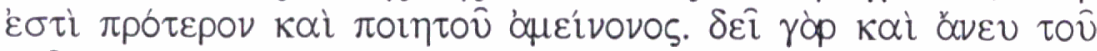

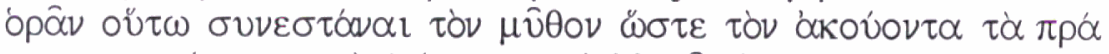

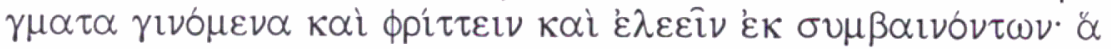

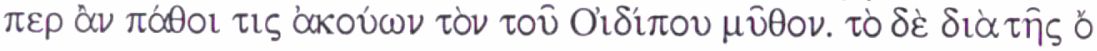




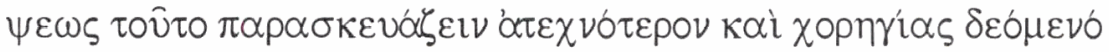 $\nu$ 'ं $\sigma \tau \imath \nu$ (id. ib. 14,1-3)}

Podem, pois, o medo e piedade ser gerados da vista, mas podem [sê-lo] ainda do encadeamento mesmo dos atos, o que é preferível e [próprio] de ótimo poeta. Pois é necessário que o mito seja composto de tal modo que, ainda que sem ver, quem ouve os atos que se geram tanto trema como se apiede pelo que ocorre. Isso padeceria [páthoi] quem ouvisse o mito de Édipo. Já o preparar isso por meio da vista [ópseos] é extratécnico e necessidade de coregia.

Por outro lado, também a epopéia e lírica se podem recitar em público por um rapsodo (id. ib. 26,6: rhapsoidoûnta; cf. Rhet. III 1,3.8) ou um declamador (id. Poet. 26,6: diáidonta) que exagerem os semeîa, ou sinais:

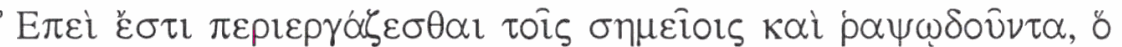

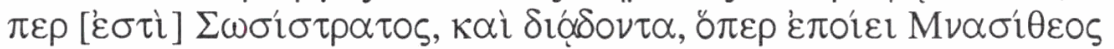

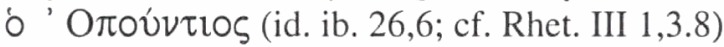

Já que podem exceder-se nos sinais [semeîois] tanto o rapsodo, o que [pode] Sosístrato, como o declamador, o que fazia Mnasíteo de Opunte.

Ora, também Horácio parece distinguir entre a declamação e a leitura de um poema outro que o trágico. Assim, neste passo:

Troiani belli scriptorem, Maxime Lolli, dum tu declamas Romae, Praeneste relegi (Hor. Ep. I 2,1-2)

O escritor da guerra de Tróia, Lólio Máximo, enquanto tu o declamas em Roma, em Preneste releio,

estaria a distinguir entre a declamação da epopéia, em que se assoma a actio, e a leitura, em que se subtrai. Enfim, assim como Horácio concorda com Aristóteles quando critica, em particular, a tragédia, assim também quando distingue, em geral, a declamação e a leitura de qualquer espécie poética.

Mas Aristóteles ainda emprega o mesmo critério na análise de espécies outras que as poéticas, a saber, na das espécies retóricas. Assim, distingue, na Retórica, entre as espécies que se prestam à recitação, isto é, à leitura acompanhada de declamação ou encenação, e as que se prestam à simples leitura; em outras palavras, distingue entre as espécies que se dirigem a ouvinte ou espectador, de um lado, e as que se dirigem a leitor, de outro. Aquelas, então, chama agonistikaí, ou combativas, e estas, graphikaí, ou escritas (Arstt. Rhet. III 12,1-6). Assim, das espécies retóricas diz que são agonistikaí a deliberativa e a judiciária (id. ib. III 12,1-2), é, porém, graphiké a epidíctica (id. ib. III 12,5-6). Ora, também Horácio emprega o mesmo critério na análise de espécies outras que as poéticas, a saber, na das espécies dialogais, ou melhor, na da espécie epistolar. Assim, na Epístola 1 do Livro 1, distingue entre a epístola, espécie do gênero dos diálogos, e a ode, espécie do gênero dos poemas, pela hypókrisis, de modo que a ode se associe à declamação, e a epístola, à leitura. 
Diz, então, que abandona a prática da ode, em que já foi muito admirado (v. 2: spectatum), para dedicar-se à da epistolografia, que lhe solicita o ouvido (v. 7: aurem), de modo que, se na Epístola 1 do Livro 2 condena o prazer do público da tragédia por ter migrado do ouvido para os olhos (v. 187-8), na outra estaria a dizer que seu prazer se volta dos olhos ao ouvido. Na verdade, também na Epístola 1 do Livro 2, tão logo aponta a Augusto as várias causas que o afastam da prática da poesia, diz que a prática a que ora se dedica é a da epistolografia (v. 250-1). Enfim, das espécies poéticas a tragédia deve, essencialmente, ser encenada, e a epopéia e ode podem, acidentalmente, ser declamadas; por oposição a todas, porém, a epístola, por assim dizer, não pode nem deve jamais ser declamada nem encenada. Assim, se das espécies poéticas umas são agonistikai por essência e outras por acidente, a epístola, contudo, espécie dialogal, seria essencialmente e sempre graphiké.'

Daí, porém, pode-se fazer uma digressão pela qual se associe a natureza escrita da epístola, elemento da hypókrisis e, daí, da elocução, a certa matéria comum à epístola, elemento da invenção. Ora, a epístola, por um lado, é contrária à encenação ou declamação e, daí, avessa ao espectador e ouvinte, isto é, ao grande público; por outro, é própria da leitura e, daí, do leitor, isto é, do pequeno público. Daí, a epístola é, por assim dizer, avessa ao público, amiga do privado; ou ainda, repugna a cidade, ama o campo. Assim, se se torna a estes versos de Horácio:

\section{Troiani belli scriptorem, Maxime Lolli, dum tu declamas Romae, Praeneste relegi (Hor. Ep. I 2,1-2) \\ O escritor da guerra de Tróia, Lólio Máximo, enquanto tu o declamas em Roma, em Preneste releio,}

repara-se, agora, que Horácio, epistológrafo, se opõe a Lólio, rapsodo, não só por associarse aquele à leitura, e este à declamação, mas por associar-se, ademais, a própria leitura ao campo (= Preneste), e a declamação à cidade (= Roma). Assim também, se se torna ao passo da Epístola 1 do Livro 1, em que Horácio diz abandonar a ode, apta à declamação, para passar à epístola, própria da leitura, repara-se, agora, que o Epistológrafo se compara, então, ao gladiador Veiânio, que teria abandonado a arena, isto é, a cidade, para passar ao campo (id. ib. I 1,5-6), oposição essa que, ademais, é assinalada por colocar-se as palavras harena e agro na posição final dos respectivos versos.

O que, então, se pode deduzir de tal digressão é que o repúdio da cidade e o elogio do campo, matéria que ocupa, por exemplo, toda a Epístola 10 e 14 do Livro 1 de Horácio, seriam, não a expressão de algum gosto particular do Autor, mas a obediência a um preceito geral da retórica e poética segundo a qual se emprega a matéria mais conveniente à elocução ou hypókrisis da espécie epistolar; numa palavra, seriam um lugar-comum determinado pelo prépon, ou decoro, daquela espécie.

\section{A phonè mikrá da epístola e o páthos da calma}

Como se disse, a léxis graphiké, ou elocução escrita, da epístola não se presta ao relevo da hypókrisis; agora, porém, é necessário especificar aquilo da hypókrisis que exatamente não se presta a pôr em relevo. Pois, como se disse também, a hypókrisis compõe-se de duas partes, a saber: de kínesis e skhémata, de um lado (Arstt. Poet. 19,7), e de phoné, de outro (id. Rhet. III 1,4), que em latim se dizem, respectivamente, actio e pronuntiatio (Cic. 
De or. II 29,79). Ora, se Aristóteles acusa, de modo geral, a hypókrisis, defende-lhe, de modo particular, a phoné ${ }^{2}$ pois se a hypókrisis, em geral, é acusada, na medida em que permite sobrepor-se a mímesis visual à sonora, a phoné, em particular, escapa a tal acusação, na medida em que é parte sonora da hypókrisis, por oposição aos skhémata, parte propriamente visual. Daí vem que a hypókrisis da epístola, se carece de kínesis e skhémata, ou actio, não carece, contudo, de phoné, ou pronuntiatio; em outras palavras, se, pela actio, a epístola se distingue totalmente das espécies poéticas, na medida em que não se presta à mímica, pela pronuntiatio, porém, distingue-se parcialmente, na medida em que, se não é encenada como a tragédia, nem declamada como a epopéia e ode, é contudo lida. Enfim, a epístola teria sua espécie própria de phoné. Ora, das phonaí que distingue Aristóteles ${ }^{3}$ parece legítimo associar-se a phonè mikrá, ou voz baixa, à leitura e, daí, à epístola, assim como, por exemplo, a phonè megále, ou voz alta, à encenação e, daí, à tragédia.

Ora, é isso que Horácio, na Epístola 7 do Livro 1, parece indicar com a expressão de contractusque leget (v. 12). Diga-se que parece porque não é essa a leitura que do verso faz, por exemplo, o pseudo-Acrão, para quem o particípio contractus estaria a indicar apenas a posição de Horácio, que leria "encolhido por causa do frio" (ps.-Acr. Ep. I 7,12: <Contractusque> ] Prae frigore). A lição apóia-se decerto na idéia, que se expressa no v. 10, de que o vate romano lerá durante o solstício de inverno (Hor. Ep. I 7,10: bruma nives). Porém, se se apoiasse a leitura no verbo leget, a que justamente se prende o particípio, poder-se-ia propor outra explicação para este. Pois se leget designa a hypókrisis própria da epístola, daí, então, também contractus. Ora, é bem do verbo traho, de que deriva contractus, que Cícero se vale para designar as espécies de uoces, de que se opõem uma à outra a uox distracta, ou voz alta (Cic. Or. 45,152: distrahere voces), e a contracta, ou baixa (id. De or. III 57,216: contractum). Assim, a expressão de Horácio poder-se-ia explicar como "lerá em voz baixa".

Demais, Aristóteles, mais que distinguir as diversas espécies de phoné, sugere ainda que se empreguem de acordo com os diversos tipos de páthos, ou afeto. ${ }^{4}$ Mas se a voz própria da epístola é a baixa, o páthos que mais lhe convém seria, ao que parece, o da praótes, ou calma. A calma, porém, Aristóteles define de modo curioso, ao admitir que é o oposto do páthos da orgé, ou melhor, katástasis kaì erémesis orgês, ou estagnação e lenitivo da ira (Arstt. Rhet. II 3,3), como se fosse, não um páthos, mas a negação de um. De fato, na Ética a Nicômaco, diz que, embora não o oposto, mas o meio-termo da ira (id. Nic. 1125 b 26: Praótes d' esti mesótes peri orgás), a calma é, não um páthos, ou afeto, mas uma héxis, ou hábito, medianeira (id. ib. 1126 b 5: mése héxis). Seja como for, a calma, páthos conveniente à voz baixa e, daí, à epístola, seria, por assim dizer, carente de páthos:

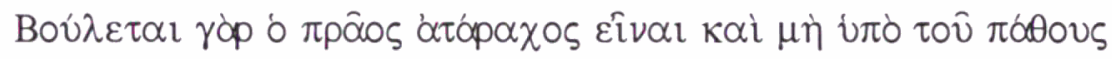
(id. ib. 1125 b 33-5)

Pois quer o calmo [prâos] estar sem turbulência, e não sob o afeto [páthous].

De fato, que a voz baixa é como carente de páthos deduz-se, por oposição, da associação que Aristóteles faz da voz alta ao páthos:

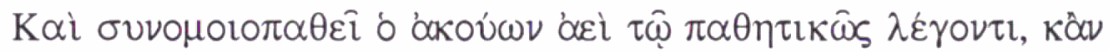

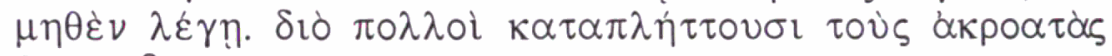

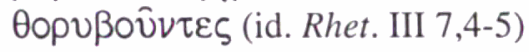


E sempre quem ouve se afeiçoa [synomoiopatheî] a quem fala afetivamente [pathetikôs], ainda que nada fale. Por isso muitos arrebatam os ouvintes ao bradar,

e que também o é a epístola deduz-se de duas associações, uma geral, outra particular. Pois, de modo geral, Aristóteles associa o páthos aos skhémata e phoné, isto é, à hypókrisis em geral:

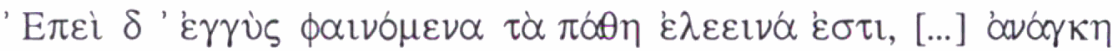

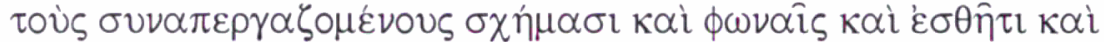

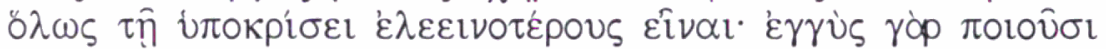

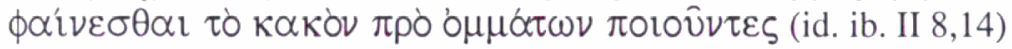

Ora, já que são piedosos os afetos [páthe] que parecem [estar] perto, [...] é necessário que sejam mais piedosos os que se excedem em feições [skhémasi], vozes [phonaîs], veste, em suma, na recitação [hypokrísei], pois fazem o mal parecer [estar] perto, ao fazê-lo [estar] ante os olhos,

donde vem que, se a epístola, por ter elocução escrita, não põe em relevo a hypókrisis toda, é como carente de páthos. De modo particular, associa a elocução escrita à akríbeia, ou exatidão, ao mesmo tempo que a hypókrisis associa à elocução combativa:

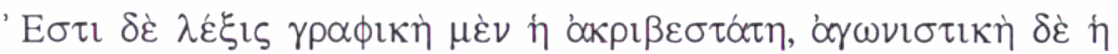
טँ

Ora, a elocução escrita [léxis graphikè], de um lado, é a mais exata [akribestáte], a combativa [agonistikè], de outro, a mais recitativa [hypokritikotáte],

e opõe a akríbeia à hypókrisis, em geral, e à phonè megále, em particular:

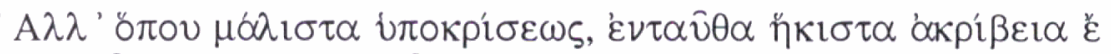

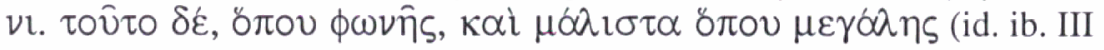
$12,5)$

Mas onde maximamente está algo da recitação [hypokríseos], ali minimamente há exatidão [akríbeia]; lá, porém, é onde está algo da voz [phonês], e maximamente da alta [megáles].

Em suma, a epístola, por ter elocução escrita, associa-se à leitura e, daí, à voz baixa e, daí, à calma, um páthos que é, por assim dizer, sem páthos; é, pois, avessa ao páthos. Daí, porém, pode-se fazer uma digressão pela qual se associe tal aversão ao páthos, que decorre da elocução, à invenção da epístola. Ora, se bem que o páthos da retórica se não confunda com o da medicina e ética, o termo sugere, contudo, algumas aproximações, já equiparativas já distintivas, daquela a estas; por exemplo, Aristóteles, na Retórica, compara o ofício da retórica ao da medicina (id. ib. I 1,14; cf. III 14,7: iatreúmata) e diz que a retórica é como um ramo da ética (id. ib. I 2,7). Assim, se se aplicassem os preceitos da medicina e ética à qualificação da epístola, que é avessa ao páthos, dir-se-ia que a matéria mais conveniente 
àquela são os medicamentos contra os páthe, seja os do corpo, objeto da medicina, seja os da alma, objeto da ética.

Assim, na Epístola 1 do Livro 1, Horácio fala de palavras que têm o poder de curar as doenças (v. 34-5), seja as do corpo (v. 28-32) seja as da alma (v. 23-42). Demais, identifica tais palavras com as lições da filosofia, em geral, e da filosofia prática ou ativa, em particular. Primeiro, pois, quando diz que abandona a poesia para ouvir as palavras de alguém (v. 1-9), que não se nomeia senão pelo indefinido quis (v. 7), estaria a pensar no magister philosophus, segundo o pseudo-Acrão (ps.-Acr. Ep. I 1,7). Demais, o Comentador entende que o dux e lar, em que Horácio diz amparar-se após ter abandonado a poesia (v. 13), sejam a doctrina ou opes ou secta ou praecepta philosophiae (ps.-Acr. Ep. I 1,13.17). De fato, a palavra lar pode-se empregar com tal acepção, bem como outras mais ou menos afins que o mesmo Horácio assim emprega, por exemplo, domus (Hor. O. I 29, 14: Socraticam [...] domum) e grex (id. Ep. I 4,16: Epicuri de grege; S. II 3,44). Enfim, o melior, em que Horácio nos insta a confiar (v. 48), é também identificado pelo pseudo-Acrão com o magister philosophus (ps.-Acr. Ep. I 1,48; cf. I 2,68). Assim também, Horácio afirma, segundo o pseudo-Acrão, que troca a poesia pela filosofia noutras Epístolas, por exemplo, na Epístola 2 do Livro 2 (id. ib. II 2,1; cf. Hor. Ep. II 2,141-4).

Em segundo lugar, a parte da filosofia a que Horácio propriamente se dedica é nomeada no seguinte passo da Epístola 1 do Livro 1:

Quid verum atque decens curo et rogo et omnis in hoc sum (Hor. Ep. I $1,11)$

O verdadeiro e decente é o de que cuido e que rogo, e todo nisso estou.

Pois o par de verum atque decens opor-se-ia ao de verum atque naturale, que se lê na Ode 28 do Livro 1 (id. O. I 28,15: naturae verique), de modo que aquele designe o objeto da filosofia prática ou ativa, isto é, da ética, e este o da filosofia teórica ou contemplativa, isto é, da física. Assim também, na Epístola 12 do Livro 1, Horácio contrapõe aquilo de que Pompeio Grosfo cuida, a saber, o verum et aequum (v. 23), par que muito se aproxima ao de verum atque decens, àquilo de que Ício cuida. Ora, de Ício diz não só que cuida da filosofia dos physici, tais como Demócrito (Hor. Ep. I 12,12) e Empédocles (id. ib. I 12,20), que investigam os fenômenos celestes (id. ib. I 12,15-20), mas que descuida da filosofia de Sócrates (id. O. I 29,13-5). Ora, Sócrates opõe-se aos physici justamente por ter voltado a filosofia do estudo dos fenômenos da natureza para o dos hábitos do homem (Arstt. M. I 6 987 a 32 - b 2; Cic. Br. 8,31).

Enfim, assim como a elocução da epístola, em geral, é avessa aos páthe, assim a invenção das Epístolas de Horácio, em particular, se identifica com os preceitos da filosofia prática ou ativa, isto é, da ética, que, justamente, ensina o homem a moderar os páthe. O que, então, se pode deduzir de tal digressão é que a proposta da filosofia ética seria, não profissão de fé do Autor, mas simples meio de harmonizar-se a invenção com a elocução da espécie epistolar; numa palavra, seria lugar-comum determinado pelo prépon daquela espécie.

\section{A akríbeia da epístola e o êthos do velho}

Ora, se a epístola, por ter, como a espécie epidíctica, léxis graphiké, é como sem páthos, as demais espécies, contudo, seja retóricas, como a deliberativa e judiciária, seja 
poéticas, como a tragédia ou também a epopéia e ode, que devem, como aquela, ou podem, como estas, ter léxis agonistiké, nem por isso são igualmente pathetikaí, ou afetivas. Das espécies retóricas, por exemplo, é a judiciária a mais apta a pôr em relevo os páthe, ou afetos, já a deliberativa, a pôr os éthe, ou costumes (Arstt. Rhet. III 12,2-4; II 1,3-4; III 7,1). De qualquer modo, a léxis da epístola não põe em relevo nem páthos nem êthos; pois a akríbeia própria da léxis graphiké opõe-se não só ao páthos, como se disse, mas ao êthos. De fato, diz Aristóteles que a pistis, ou fé, produzida pelo êthos é tanto maior quanto menos akríbeia, ou exatidão, e mais amphídoxon, ou ambigüidade, há (id. ib. I 2,4). Porém, assim como o não-relevo do páthos, próprio da léxis da epístola, não significa que esta não tenha páthos, mas que tenha um que consiste, por assim dizer, na negação do páthos, assim o nãorelevo do êthos.

Demais, Aristóteles, sobre distinguir várias espécies de éthe, sugere ainda que se empreguem de acordo com os páthe as héxeis, ou hábitos, as helikíai, ou idades, e as týkhai, ou sortes (id. ib. II 12,1). Ao falar, então, do êthos dos presbýteroi, ou velhos, diz que estes não agem impelidos pelas epithymíai, ou apetites, mas contidos pelo kérdos, ou ganho, de modo que se possam dizer, não pathetikoí, mas sophronikoí, isto é, não afetivos, mas moderados (id. ib. II 13,13; I 10,10). Mais que isso, porém, diz que, por viver conforme o ganho, vivem mais pelo logismós, ou cálculo, que pelo êthos (id. ib. II 13,14; I 10,9). Em suma, o êthos próprio da idade dos velhos opor-se-ia não só ao páthos, mas, de algum modo, ao êthos mesmo; nesse sentido, pois, seria o êthos mais conveniente à léxis da epístola.

Ora, na Epístola 1 do Livro 1 e na Epístola 2 do Livro 2, em que Horácio aponta a Mecenas e Lólio, respectivamente, as causas que o afastam da poesia, a par do estudo da filosofia, nomeia-se outra causa: a idade avançada. Assim, diz a Mecenas:

Non eadem est aetas, non mens [...] (Hor. Ep. I 1,4; cf. v. 8)

Não é a mesma a idade, nem a mente [...],

e a Lólio:

Singula de nobis anni praedantur euntes (id. ib. II 2,55; cf. v. 51-7, 142)

Ao passar, os anos depredam-nos as coisas uma a uma.

Daí, porém, poder-se-ia deduzir que a matéria que mais convém à epístola é a da morte, a que, se não pelo acaso, ao menos pela necessidade, o velho se avizinha mais que o adulto ou a criança. Ora, tal parece ser o sentido de uns versos da Epístola 1 do Livro 1 de Horácio. Diga-se que parece porque a matéria da morte lá se entrevê por um sentido mais alegórico que literal. Ora, tão logo nomeia sua ocupação com o sobrecitado par de verum atque decens, de modo a identificar aquela com a filosofia ética, Horácio diz:

Aeque pauperibus prodest, locupletibus aeque (id. ib. I 1,25)

Igualmente aos pobres é útil, aos ricos igualmente,

o que faz pensar, antes de tudo, que o estudo da filosofia ética é igualmente útil a ricos e pobres. Porém, a idéia de indistinção perante ricos e pobres faria pensar, ademais, na morte, pois o mesmo Horácio diz na Epístola 2 do Livro 2: 


\author{
[...] Si metit Orcus \\ grandia cum parvis [...] (id. ib. II 2,178-9) \\ [...] Se ceifa Orco \\ o grande com o pequeno [...].
}

Ora, a discussão sobre a importância do estudo da filosofia ética, que se lê na Epístola 1 do Livro 1, é precedida por outra em que Horácio diz que já está velho para escrever versos (v. 1-4) e que, como um gladiador, deve retirar-se da arena, para que, já velho, não tenha de suplicar os aplausos do público (v. 4-5). Por sua vez, os versos citados da Epístola 2 do Livro 2 precedem a discussão sobre o momento de a pessoa, já velha, retirar-se da vida (v. 205-16). Ora, percebe-se que o confronto não é aleatório, se se atenta no vocabulário; pois quando, numa Epístola, diz Horácio que o gladiador não deve suplicar, emprega o verbo exorare (id. ib. I 1,6), e quando, noutra, refere a implacabilidade de Orco na hora da morte, qualifica o deus pela expressão non exorabilis (id. ib. II 2,179). Assim também, ao comparar, numa Epístola, com o gladiador que, já velho, se deve retirar da arena, o cavalo que, já avelhentado, deve ser solto e abandonar as corridas, emprega o verbo solve (id. ib. I 1,8), que, noutra, emprega com a acepção de morrer, como explica o mesmo Autor:

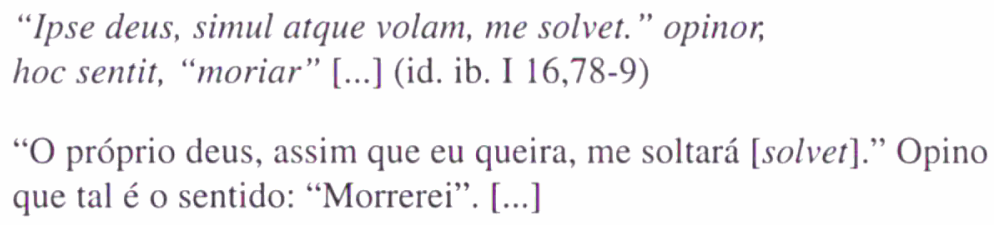

Demais, Horácio conclui tais versos dizendo que a morte é ultima linea, ou última linha, que, em sentido alegórico, faria pensar na reta de chegada da corrida do cavalo da Epístola 1 do Livro 1 (cf. v. 9: ad extremum; v. 6: extrema). Enfim, assim como, na Epístola 1 do Livro 1, o cavalo já velho, se teimar em correr, acabará ridículo (id. ib. I 1,9: ridendus), assim também, na Epístola 2 do Livro 2, a pessoa já velha, se se obstinar em viver (id. ib. II 2,216: rideat). Logo, pode-se dizer que, a par do estudo da filosofia ética, as causas que, na Epístola 1 do Livro 1 e na Epístola 2 do Livro 2, afastam Horácio da prática da poesia seriam os cuidados com a idade avançada e, daí, com a morte iminente; tal é a matéria daquelas Epístolas.

Enfim, à elocução da epístola o êthos que mais convém é o do velho; daí, a matéria que mais lhe convém é a da morte. O que, então, se pode deduzir de tal digressão é que o avançado da idade e a iminência da morte seriam, nem dado biográfico nem algum medo mórbido do Autor, mas simples meio de harmonizar-se a invenção com a elocução da espécie epistolar; numa palavra, seriam lugar-comum determinado pelo prépon daquela espécie.

\title{
Conclusão
}

A seguir, resumem-se, primeiro, os preceitos concernentes à qualificação da hypókrisis e léxis da epístola, bem como à conveniência entre aquelas e a matéria; depois, aplicam-se tais preceitos à leitura de um passo das Epístolas de Horácio. Assim, tem-se, primeiro, isto: 
1. A epístola, por ter léxis graphiké, não admite a hypókrisis ou actio toda, ou melhor, não admite kínesis nem skhémata, ou actio propriamente dita, mas apenas phoné ou pronuntiatio;

1.1. daí, por não ser apta a declamar-se em público, mas apenas a ler-se em particular, a matéria que mais lhe convém são o repudio da cidade e o elogio do campo.

2. Das phonaí a que mais convém à epístola é a phonè mikrá ou uox contracta, à qual, por sua vez, mais convêm:

2.1. o páthos da calma, que é como sem páthos,

2.1.1. donde vem que a matéria mais conveniente à epístola seja a discussão filosófica, ou melhor, o estudo da filosofia prática ou ativa;

2.2. e o êthos do velho, que não só se opõe ao páthos mas, por assim dizer, ao êthos mesmo,

2.2.1. donde vem que a matéria mais conveniente à epístola seja a da morte.

Demais, a conveniência entre elocução e invenção epistolar, investigadas aqui pelo confronto de Horácio com Aristóteles, pode bem resumir-se com este passo de Demétrio:

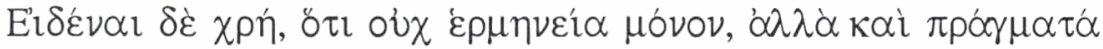

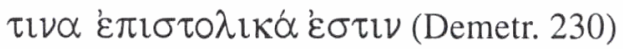

Ora, é preciso saber que não só hermeneía [= elocução], mas também alguns prágmata [= invenção] epistolares há.

Em segundo lugar, aplicam-se aqueles preceitos à leitura do prólogo da Epístola 1 do Livro 1, cujos versos, já antes citados esparsamente, agora se lêem numa tira:

Prima dicte mihi, summa dicende Camena, spectatum satis et donatum iam rude quaeris, Maecenas, iterum antiquo me includere ludo. non eadem est aetas, non mens. Veianius armis Herculis ad postem fixis latet abditus agro, ne populum extrema totiens exoret harena. est mihi purgatam crebro qui personet aurem "solve senescentem mature sanus equum, ne peccet ad extremum ridendus et ilia ducat." Nunc itaque et versus et cetera ludicra pono; quid verum atque decens curo et rogo et omnis in hoc sum; condo et compono quae mox depromere possim (Hor. Ep. I 1,1-12)

À primeira [antes] vindo, à minha última Camena [agora] vindouro, requisitas de mim, já com o florete dadivado e tão admirado, Mecenas, que de novo me encerre na antiga diversão.

Não é a mesma a idade, nem a mente. Veiânio, penduradas as armas ao poste de Hércules, esconde-se ao longe no campo para que não implore tanto o público no extremo da arena. Há quem sempre me purgue, ao soprar, o ouvido:

"Solta, [se és] são, o cavalo, avelhentado, a tempo, para que não 
tropece no extremo [da pista] risível, e a ilharga mostre".

Agora, pois, tanto os versos como o divertimento restante deponho; o verdadeiro e decente é o de que cuido e que rogo, e todo nisso estou; construo e componho o que logo eu possa sacar.

De acordo com os preceitos acima resumidos, é de reparar, primeiro, a matéria do elogio ao campo e repúdio da cidade, pois Horácio, epistológrafo, compara-se a Veiânio, gladiador, que justamente abandona a arena, isto é, a cidade, para recolher-se ao campo. Em segundo, é de reparar a matéria da filosofia ética, pois Horácio deixa os versos e divertimento, isto é, a poesia, para cuidar do verdadeiro e decente. Em terceiro, é de reparar o êthos do velho, pois Horácio tanto diz que abandona o lúdico, próprio do jovem, por não ter mais a idade de antes, como se compara a cavalo avelhentado. Enfim, é de reparar a matéria da morte, que se entrevê na alegoria do cavalo que, se teima em correr, acaba risível, à maneira da pessoa que, se se obstina em viver, acaba ridícula. Assim, o prólogo da Epístola 1 do Livro 1, mais que abrir a referida Epístola, serviria, na verdade, de prólogo a toda a coleção das Epístolas de Horácio, por enfeixar tudo que pertence à matéria epistolar.

\section{Notas}

1 - Também a sátira, outra espécie dialogal conhecida de Horácio, é por este associada à leitura e, daí, oposta à recitação: [...] Cum mea nemo/ scripta legat volgo recitare timentis [...] (Hor. S. I 4,22-3; cf. v. 71-6). [...] Já que ninguém os meus/ escritos lê, temendo eu recitar ao vulgo [...]; Saepe stilum vertas, iterum quae digna legi sint/ scripturus, neque te ut miretur turba labores, / contentus paucis lectoribus. an tua demens/ vilibus in ludis dictari carmina malis? (id. ib. I 10,72-5). Amiúde invertas o estilete, e o que seja digno de reler-se/ escreverás; nem trabalhes por ser admirado da turba,/ contenta-te de poucos leitores. Ou preferes/ em diversões vis teus poemas recitar demente?

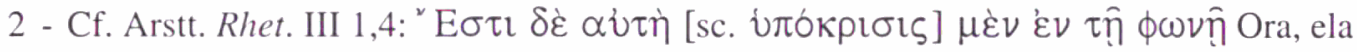
mesma [sc. hypókrisis], pois, está na voz [phonêi]; Cic. De or. III 60,224: Ad actionis autem usum atque laudem maximam sine dubio partem vox obtinet Ora, para o uso e louvor da ação [actionis], detém a voz [vox] a parte indubitavelmente principal.

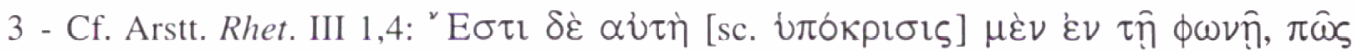

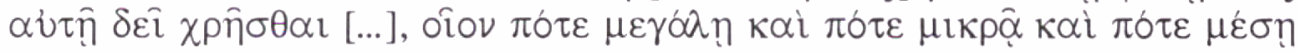
Ora, ela mesma [sc. hypókrisis], pois, está na voz [phonêi], em como é necessário usar desta [...], isto é, quando [é necessário usar] da alta, quando da baixa, quando da média.

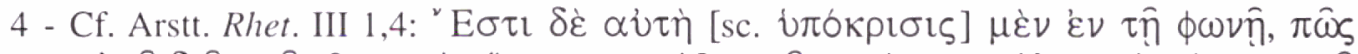

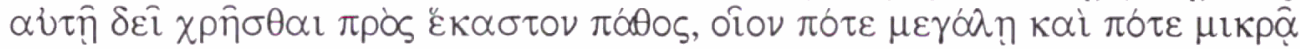

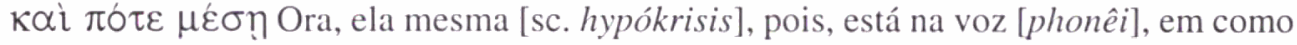
é necessário usar desta para cada afeto [páthos], isto é, quando [é necessário usar] da alta, quando da baixa, quando da média. 


\section{Referências bibliográficas}

ARISTOTLE. The art of rhetoric. With an English translation by J. H. Freese. 8. ed. Cambridge / London: Harvard University Press, 1991.

The poetics. With an English translation by W. H. Fyfe. 5 ed. Cambridge / London: Harvard University Press, 1953.

HORACE. Satires. Epistles. Ars poetica. With an English translation by H. R. Fairclough. 13 ed. Cambridge / London: Harvard University Press, 1991.

MARTINHO DOS SANTOS, M. The epistle as example of written composition. Classica, São Paulo, 11/12, p. 233-246, 1998/1999.

ABSTRACT: By the collation of Horace's Epistles and Aristotle's Poetics and
Rethoric, I investigate first the hypókrisis of the epistle, so as to qualify it as
essencially graphiké and, thus, as researved, not to an audience, but to a reader.
Then I infer from that quality the most suitable matter to the epistle, so as to
understand this suitability as prépon of the epistle; for instance, in Horace's
Epistles, the praise of country and the renouncement of town may be, in this
sense, not Horace's idiosyncrasy, but the matter which better harmonizes with
the elocution that is suited for reader, that is, for the private life [= country], and
renounces the audience and spectator, that is, the public life [=town].
KEY-WORDS: epistolography; Horace; poetry; rhetoric; Aristotle; hypókrisis;
written and oral composition; prépon. 